\title{
Student Interaction with Online Course Content: Build It and They Might Come
}

\author{
Meg Murray, Jorge Pérez, Debra Geist, and Alison Hedrick \\ Kennesaw State University Kennesaw, GA USA
}

\author{
mcmurray@kennesaw.edu; jperez@kennesaw.edu; \\ dgeist1@kennesaw.edu; ahedric1@kennesaw.edu

\section{Executive Summary}

Online learning continues to expand at educational institutions around the globe. Educators must better understand how interaction with online course content impacts student engagement and learning. Advances in technology amplify the imperative to gain further insights into how delivery of course materials can enhance and support the learning process. This study investigates student patterns of access to instructional resources provided in an asynchronous online digital literacy course offered at a regional university in the United States. Frequency counts and access rates collected from a learning management system were used to assess patterns of student retrieval of course materials in four categories: core materials, direct support, indirect support and ancillary materials. Results were consistent with student survey responses and indicate that students selectively access course content based upon the degree to which they perceive it will positively influence performance and outcomes on assignments and assessments.

Keywords: Online learning, learner-content interaction, instructional materials, distance education, online course design.

\section{Introduction}

More and more students are enrolling in online courses. The growth in distance education is a worldwide phenomenon. Online course offerings transcend the boundaries of time and space, creating new opportunities for students, faculty, and educational institutions (Mayadas, Bourne, \& Bacsich, 2009). It has been predicted that online courses will soon become an established offering in most colleges and universities and that by 2014 the majority of students will take at least some of their college classes online (Nagel, 2009). While distance education in some form or another has been around for decades, the evolution of the Internet has facilitated the rapid expansion of online courses. Research has shown online learning can be as effective as face-to-face instruction, but to be effective online courses must be well-designed, provide access to high quality instructional materials, and be led by experienced and motivated faculty (Mayadas et al.). As the number

Material published as part of this publication, either on-line or in print, is copyrighted by the Informing Science Institute. Permission to make digital or paper copy of part or all of these works for personal or classroom use is granted without fee provided that the copies are not made or distributed for profit or commercial advantage AND that copies 1) bear this notice in full and 2) give the full citation on the first page. It is permissible to abstract these works so long as credit is given. To copy in all other cases or to republish or to post on a server or to redistribute to lists requires specific permission and payment of a fee. Contact Publisher@InformingScience.org to request redistribution permission. of students learning online increases, understanding how they engage and interact with course content becomes important. This study investigates student patterns of access to instructional resources provided in an online course environment. Examining student access to course content provides insights into ways course materials can be better de- 
signed to enhance and support the learning process.

Globally, by 2020, the demand for 'seats' in higher education is projected to reach 200 million, from the current demand of 115 million (Redden, 2009). Many of those 'seats' will be offered as online classes. In the United States, the Department of Education and an independent research group track enrollments in online courses. The most recently released US Department of Education report, The Condition of Education, 2011, analyzed data collected during the 2007-2008 academic year. Any course accessed over the Internet, synchronous and asynchronous, is counted as an online course. The report cited 4.3 million, or $20 \%$ of all undergraduates in the US, took an online course during the 2007-2008 academic year. This represents a four percent increase from 2003-2004, the last time data was reported (Aud, Hussar, Kena, Bianco, Frohlich, Kemp, and Tahan, 2011). Going the Distance: Online Education in the United States, 2011, an independent survey of the state of online learning in higher education in the United States, cited 6.1 million, or $31 \%$ of all undergraduates, enrolled in an online course during the fall semester of 2010 (Allen \& Seaman, 2011). This represented an increase of more than 560,000 students, a $10 \%$ increase from the previous year. The study also indicated the growth rate in online course enrollments was ten times more than the overall growth rate in higher education enrollments (Allen \& Seaman, 2011). A majority of institutions (65.5\%) also identified online education as a critical component of the institution's long-term strategy (Allen \& Seaman, 2011).

There are many drivers promoting the growth of online education. These include the ability to reach an extended student population, thwart competition from other institutions, and address budgetary pressures resulting from the latest economic downturn. Many believe the traditional 'bricks-and-mortar' only model of higher education is unsustainable (Fain, 2010). On the other hand, others argue that the integration of technology within society is the primary driver for the development of online courses (Brooks, 2009). Given this premise, Brooks identifies eight reasons why institutions of higher education should offer online courses. Online courses provide more opportunities to create active learning environments, address the learning styles of today's technology connected students, foster a greater variety of experiences outside the classroom, teach students how to do independent research, make college more accessible to students, make attending college more affordable, teach students about making ethical choices, and create online courses that meet high quality standards for teaching and learning.

\section{Literature Review}

As online learning has taken hold in the educational arena, its position as an equivalent alternative to traditional face-to-face instruction has been widely researched. Bollinger and Wasilik (2009) reviewed numerous studies regarding the overall performance of students engaged in online learning; none of the studies indicated a lower level of student performance by students engaged in this delivery method. On the contrary, a substantial review of online course evaluation reports covering a six-year span indicated online instruction demonstrated an improvement over the traditional classroom (Olson and Wisher, 2002 as cited in Bollinger \& Wasilik). An even more substantial study is found in a meta-analysis conducted by Shachar and Neumann (2010). This study covered the twenty-year period from 1990-2009. The study concludes, "It is clear that the experimental probability of attaining higher learning outcomes is greater in the online environment than in the face-to-face environment" (p.10). An additional meta-analysis of online learning, prepared by the US Department of Education, reviewed over a thousand empirical studies published from 1996 through 2008. The findings from this meta-analysis concluded, “...on average, students in online learning conditions performed modestly better than those receiving face-to-face instruction” (Means, Yoyama, Murphy, Bakia, \& Jones, 2010, p. ix).

Not only is online learning proving to provide quality education, the distance learning approach is proving both successful and satisfying for students. The Sloan Consortium (2002) reports "Stu- 
dents are successful in learning online and are typically pleased with their experiences” (p.1). To further refine student satisfaction with online learning, the Sloan Consortium maintains satisfaction is directly tied to the use of timely and personalized learning resources ("Quality Framework,” n.d., para. 6). These personalized learning resources exist in abundance on the Internet, leaving no excuse for an online course to not only offer a high level of educational value, but also a variety of content, appealing and attractive to students (Haley, 2010). Flat resources, in the form of static text documents, are insufficient for building online courses resulting in a high level of interactive engagement and student satisfaction; multimedia instruction has been identified as an important element of student satisfaction in an online environment (Liaw, 2008 as cited in Bollinger \& Wasilik, 2009; Lin, Lin, \& Laffey, 2008 as cited in Bollinger \& Wasilik, 2009). Haley (2010) asserts faculty can put both talent and versatility to work in developing an online educational experience that is both attractive and inspiring by incorporating a variety of media content including text, audio, video, and images.

Effective online learning, however, is the result of a well-planned instructional design effort that meets pedagogical needs. Much research has been done to apply instructional design principles to develop frameworks, models, and taxonomies that can be used to design online courses with high potential for achieving positive learning outcomes. Building on the research in effective strategies for creating online learning environments, Siragusa, Dixon, and Dixon (2007) incorporated 24 recommendations into the development of an Instructional Design for Online Learning (IDOL) model that can be used to assist in the instructional analysis, design, delivery, and evaluation of online courses. The dimensions of the model include adhering to established instructional design models, providing adequate content, implementing a well-defined and well-organized course infrastructure, utilizing an online learning management system, and including opportunities for feedback and a course evaluation process.

Within an online course, the provision for content is a major area of consideration. Content delivered in an online course needs to be complete, relevant, and accurate (Siragusa et al., 2007). It must include all the information necessary for students to successfully complete course requirements. Siragusa et al. (2007) outlined these resources to include detailed content, learning activities, assignment requirements, and supporting materials. Brown and Voltz (2005) maintain that "educational materials that have been effectively designed will facilitate the achievement of desired learning outcomes for students" (p.1.). They cite six design elements that should be present in the collection of resource materials provided to students in an online course. These elements mandate learning resources include an activity or task that students must perform, a scenario or story that motivates a student to perform, opportunities for feedback, an appropriate delivery medium, consideration of the context of the learning environment, and consideration of the influence the resource will have on student learning. Applying these six design elements generates instructional materials that contribute to the totality of the learning experience.

The evolution of Learning Management Systems (LMS) has provided an infrastructure that readily supports online course offerings. The quality and ease of use (such as intuitive navigation) of the LMS contribute to the ultimate success and overall satisfaction of an e-learning course. LMSs have made it much easier to develop online courses that incorporate a variety of learning resources. Unfortunately, this abundant variety does not always benefit students. Some online courses suffer because the features and tools offered by the LMS, or the sheer quantity of educational resources provided to the student, do not align with course learning objectives (Koszalka \& Ganesan, 2004). This is often due to the fact course developers include extra options and resources simply because they can. To help prevent this from happening, Koszalka and Ganesan (2004) developed an instructional design taxonomy for helping course developers strategically align LMS features with the teaching and learning goals of the course. The underlying principle 
of the taxonomy stipulates that course developers think strategically when designing the course to ensure the materials and features provided map directly to supporting course learning outcomes.

Measuring quality in an online course can be difficult. Many different approaches exist, but no standard guidelines with which to measure quality have been established. Greenberg (2010) contends quality assessments are taking place at the programmatic level and above (e.g., quantitative characteristics such as grades, graduation rates, and surveys) when, instead, they should be examined during the design of the course and include the course creators. An example of such an approach to insuring quality in online course development is the Quality Matters (QM) project. Quality Matters (QM) is a not-for-profit subscription service that provides tools and training for administering a quality assurance program for online courses. It consists of a set of standards for the design of online and blended courses, as well as a faculty-driven peer review process and professional development program. The standards come from a detailed review of existing research literature and are updated every few years, most recently in 2011 ("Quality Matters,” 2011). Within the QM review process, proposed online courses are peer-reviewed using a standardized rubric. The rubric evaluates the course overview and introductions, learning objectives, assessment and measurement, instructional materials, learner interaction and engagement, course technology, learner support, and accessibility. Criteria evaluated under the rubric were selected as those characteristics shown to positively influence student learning (Legon \& Runyon, 2007). The intent of the process is not to pass judgment, but to improve the design of a course as it moves through the review process.

To measure the validity of the QM rubric, Legon (2006) compared it with a set of standards endorsed by the Council for Higher Education Accreditation and the eight regional accrediting agencies. He found the rubric to be "fully consistent with published accreditation standards for online education" and concluded it "can demonstrate an institution's commitment to quality assurance of its online offerings and its success in achieving a well-defined standard for course design” (p.9). Ralston-Berg and Nath (2008) took it a step further and found that all items in the QM rubric were valuable as students indicated these features are desirable in an online course. Legon and Ruynon (2007) studied the impact of QM review on student attainment of learning outcomes and found student learning and satisfaction increased for courses redesigned using QM criteria. Well-designed online courses correlate positively to student attainment of learning outcomes.

\section{Research Questions}

Interaction is a fundamental component of learning. Moore (1989), in his seminal piece, defined three categories of interaction evident in distance education: learner-teacher, learner-learner, and learner-content. Learner-teacher refers to the interaction between student and expert. These types of interaction take on many forms including delivery or presentation of information, student guidance, student-teacher dialog, feedback, and student encouragement. Learner-learner interaction refers to the exchange of information and ideas amongst students as well as collaborative activities in which students engage to complete course projects and assignments. Learner-content interaction, according to Moore (1989), is "a defining characteristic of education" and "without it there cannot be education" (p. 1). It is through content interaction that students internalize information they encounter. Ultimately, content interaction results in "changes in learner understanding, learner perceptions or even cognitive structures of the learner's mind” (Moore, 1989, p.1). It is the learner-content interaction that this study investigates.

In an online course, all content and course materials are delivered electronically. Consequently, learner-content is the principal mode of interaction and the instructional materials the primary medium through which learning is facilitated. As such, this study investigates student interaction with course materials in an online course and asks the following questions: 
1. What are the patterns of student access to course materials in an online course and what types of materials do students access most often?

2. Are patterns of access related to student success as measured by course grades?

3. Are student perceptions of access patterns consistent with other evidence?

4. What reasons do students give for not accessing course materials?

\section{Methodology}

The purpose of this study is to examine student access to course materials in an online course environment. The framework of investigation was an exploratory study using descriptive research methodologies. Specifically, this study analyzed student access patterns in an asynchronous online digital literacy course offered in the spring 2011 semester at a regional university in the United States. The course is open to all students at the university and students from different majors enroll in the course. The course was offered in both an online and hybrid format. Of the 450 students who enrolled in the course in spring 2011, 120 students enrolled in an online section.

Of the 120 students who enrolled in the online course, 100 completed the course. These students are included in this study. Table 1 depicts the demographic distribution of the students in the course. The majority of students were female, upper-class students of traditional college-age. The over representation of upper-class students is most likely due to the fact students register for classes based on the number of course hours completed. In other words, upper-class students register for classes prior to under-class students.

\begin{tabular}{|llrr|}
\hline \multicolumn{4}{c}{ Table 1: Student Demographics } \\
\hline Gender & & Count & Percent \\
& Male & 38 & $38.00 \%$ \\
& Female & 62 & $62.00 \%$ \\
& & Count & Percent \\
& $18-23$ & 60 & $60.00 \%$ \\
Class Standing & $24-29$ & 24 & $24.00 \%$ \\
& over 30 & 16 & $16.00 \%$ \\
& & Count & Percent \\
& Sreshman & 2 & $2.00 \%$ \\
& Sophomore & 28 & $28.00 \%$ \\
& Junior & 31 & $31.00 \%$ \\
& Senior & 39 & $39.00 \%$ \\
\hline
\end{tabular}

\section{Course Structure}

The online course referenced in this study was an information technology/digital literacy course. The course was designed to amplify student understanding and application of computing technologies to solve problems. Topics covered included computer hardware and software, productivity software, Internet research skills, networking, and the Internet. The course was divided into 14 weekly modules. Each module included a module guide outlining learning objectives, activities, assignments, and assessments assigned for the week. The activities section directed students to associated readings in the course assigned electronic textbook as well as to additional instructional materials including posted PowerPoint lecture notes, links to online tutorials and instructional videos, related materials found on the Web, and other instructor prepared documents. An 
assignment and an assessment (online quiz) were assigned each week. Assignments varied ranging from discussion posts to project-based activities. Overall course assessment was based on weekly assignments and quizzes (50\%), a midterm examination (25\%) and a final examination (25\%).

The university from which this study was conducted subscribes to the Quality Matters course review process. Consequently the course referenced in this study underwent a comprehensive peerbased review. This review assessed how well course materials and the organization of those materials adhered to 40 identified standards of quality. The course met all standards and received high commendation for those areas related to instructional materials and course organization.

As an online asynchronous course, all course materials and associated resources were provided to the students within a university-supported learning management system accessible via the Web. Access to course materials posted within this LMS is analyzed in this study. It should be noted, however, access to the e-textbook and a course-required computer-based-training program were not tallied. These resources were bundled together as part of a course packet that students enrolled in the course accessed as part of a required online registration process.

The total number of different course resources posted in the LMS was 92. To facilitate the evaluation of access to these resources, they were organized into four different categories, core material, direct support, indirect support, and ancillary materials. Core material was comprised of the syllabus and all other documents and resources provided to help students with course logistics, course navigation, and use of course technologies. Direct support resources provided direct guidance or instructional support necessary to complete course assignments and assessments. Module guides and assignment instructions fall under this category. Assigned readings from the textbook are not included, as previously discussed. Indirect support included resources that augment information provided in the text. These materials, such as lecture notes and tutorials, were directed at helping students achieve a high level of success in meeting learning outcomes for a particular module. Ancillary materials provided students with additional resources to enhance learning and deepen their understanding of topics presented.

The data used in this study was collected through the course learning management system. The LMS tracked individual student access to all posted resources. For the purposes of this study, the only count reported was whether or not a student opened a resource. The number of times a resource was viewed was not tracked. Simple statistics were used to describe the data. An access rate is reported as a percentage of students who accessed a resource or collection of resources. A Pearson product-moment correlation was used to compare student access rates with student grades. Descriptive statistics were also used to report findings of student perceptions of resource access.

\section{Findings}

Frequency counts and access rates were used to assess patterns of student access to the four categories of course materials as previously classified. 


\section{Core Material}

The category of core material included 13 different resource items. All students accessed at least one of the resources - the course syllabus. The other documents most commonly viewed were the welcome message (96\%) and the instructions for enrolling in the computer-based training program that accompanied the e-textbook (99\%). The overall access rate for all resources within the computer support category was $71.15 \%$. Access patterns for core material resources are shown in Table 2.

Table 2: Student Access Rates for Core Material Resources

\begin{tabular}{|c|c|c|c|}
\hline Resource Name & $\begin{array}{c}\text { \# of Students } \\
\text { (who Accessed this } \\
\text { Resource) } \\
\end{array}$ & $\begin{array}{c}\text { Access } \\
\text { Rate } \\
\end{array}$ & \\
\hline Course Welcome Message & 96 & $96.0 \%$ & \\
\hline Course Netiquette & 76 & $76.0 \%$ & \\
\hline Course Syllabus & 100 & $100.0 \%$ & \\
\hline Course Technology Requirements & 75 & $75.0 \%$ & \\
\hline Schedule of Topics & 74 & $74.0 \%$ & \\
\hline Course Navigation & 58 & $58.0 \%$ & \\
\hline Course Grading Rubric & 46 & $46.0 \%$ & \\
\hline Instructions for e-Textbook Registration & 74 & $74.0 \%$ & \\
\hline Instructions for CBT Registration & 99 & $99.0 \%$ & \\
\hline Getting Started using the CBT Training Programs & 68 & $68.0 \%$ & \\
\hline Getting Started using the CBT Projects & 66 & $66.0 \%$ & \\
\hline How To Create \& View Reports in the CBT & 16 & $16.0 \%$ & \\
\hline Instructions for Installing the VMware Client & 77 & $77.0 \%$ & \\
\hline Access Rate for All Resources in this Category & & & $71.2 \%$ \\
\hline
\end{tabular}




\section{Direct Support}

Eighteen direct support resources were provided. These included weekly module guides and instructions for completing various assignments. All students accessed multiple resources in this category. However, not all students accessed every resource and no resource was accessed by all students. The overall access rate for all resources in this category was $78.8 \%$. Access rates for direct support resources are shown in Table 3.

\begin{tabular}{|l|c|c|c|}
\hline \multicolumn{3}{|c|}{ Table 3: Student Access Rates for Direct Support Resources } \\
\hline Resource Name & $\begin{array}{c}\text { \# of Students } \\
\text { (who Accessed this } \\
\text { Resource) }\end{array}$ & $\begin{array}{c}\text { Access } \\
\text { Rate }\end{array}$ & \\
\hline Module 01 Guide & 86 & $86.0 \%$ & \\
\hline Module 02 Guide & 86 & $86.0 \%$ & \\
\hline Module 03 Guide & 80 & $80.0 \%$ & \\
\hline Module 04 Guide & 58 & $58.0 \%$ & \\
\hline Module 05 Guide & 86 & $86.0 \%$ & \\
\hline Module 06 Guide & 78 & $78.0 \%$ & \\
\hline Module 07 Guide & 64 & $64.0 \%$ & \\
\hline Module 08 Guide & 78 & $78.0 \%$ & \\
\hline Module 09 Guide & 69 & $69.0 \%$ & \\
\hline Module 10 Guide & 73 & $73.0 \%$ & \\
\hline Module 11 Guide & 75 & $75.0 \%$ & \\
\hline Module 12 Guide & 67 & $67.0 \%$ & \\
\hline Module 13 Guide & 74 & $84.0 \%$ & \\
\hline Module 14 Guide & 85 & $85.0 \%$ & \\
\hline $\begin{array}{l}\text { Assignment Instructions Mobile } \\
\text { Devices }\end{array}$ & 94 & $94.0 \%$ & \\
\hline $\begin{array}{l}\text { Assignment Instructions Infor- } \\
\text { mation Security }\end{array}$ & 93 & $98.0 \%$ & \\
\hline $\begin{array}{l}\text { Assignment Instructions Web } \\
\text { Page }\end{array}$ & 84 & & \\
\hline $\begin{array}{l}\text { Instructions for Uploading Files } \\
\text { to a Web Server }\end{array}$ & & & \\
\hline Access Rate for All Resources in & & & \\
\hline \hline
\end{tabular}




\section{Indirect Support}

Materials classified as indirect support resources augmented direct support resources providing students with extra instructional materials. These resources were designed to enhance student understanding and improve their performance on assignments and assessments. Twenty-one different resources were provided in this category. The majority of students (98) accessed resources in this classification. Two students did not. The overall access rate was $63.0 \%$. Variance in access rates by specific resource was observed ranging from a low of $35 \%$ to a high of $87 \%$. No specific pattern by type of resource was evidenced. For instance, lecture notes had both the highest rate of access and the lowest. Access rates for indirect support resources appear in Table 4.

\begin{tabular}{|l|r|r|l|}
\hline \multicolumn{4}{|c|}{ Table 4. Student Access Rates for Indirect Support Resources } \\
\hline & $\begin{array}{c}\text { \# of Students } \\
\text { (who Accessed this } \\
\text { Resource) }\end{array}$ & Access Rate & \\
\hline Resource Name & 81 & $81.0 \%$ & \\
\hline Lecture Notes: Digital Technology & 87 & $87.0 \%$ & \\
\hline Lecture Notes: Hardware & 75 & $75.0 \%$ & \\
\hline Lecture Notes: Boot Process & 56 & $56.0 \%$ & \\
\hline Lecture Notes: Software & 75 & $75.0 \%$ & \\
\hline Lecture Notes: Operating System & 81 & $81.0 \%$ & \\
\hline Tutorial: Function of an OS \{web link\} & 75 & $75.0 \%$ & \\
\hline How To Create a Formula in Excel & 42 & $42.0 \%$ & \\
\hline Excel Cell References & 54 & $54.0 \%$ & \\
\hline Excel Functions & 52 & $52.0 \%$ & \\
\hline Lecture Notes: Databases & 72 & $72.0 \%$ & \\
\hline Lecture Notes: Database Tables & 59 & $59.0 \%$ & \\
\hline Lecture Notes: Internet & 35 & $35.0 \%$ & \\
\hline Intute Internet Research Skills \{web link\} & 49 & $49.0 \%$ & \\
\hline Intute Virtual Training \{web link\} & 59 & $59.0 \%$ & \\
\hline Internet Detective tutorial \{web link\} & 47 & $47.0 \%$ & \\
\hline Lecture Notes: Telecommunications & 68 & $68.0 \%$ & \\
\hline Lecture Notes: Information Security & 53 & $53.0 \%$ & \\
\hline HTML tutorials & 59 & $59.0 \%$ & \\
\hline Step-by-Step HTML & 71 & $71.0 \%$ & \\
\hline Web Page Example & $73.0 \%$ & \\
\hline Access Rate for All Resources in this Category & & & $63.0 \%$ \\
\hline
\end{tabular}




\section{Ancillary Materials}

Forty different ancillary resources were provided. The ancillary materials provided information in addition to what was available in other posted resources. For instance, many of these resources were videos that demonstrated a particular concept. Although the overall access rate for ancillary materials was $29 \%$, all but one student accessed at least one ancillary resource. In addition, access rates varied widely by resource. The lowest access rate was $8 \%$, the highest was $81 \%$. Students are quite selective about the ancillary materials that they elect to review. Access rates for ancillary resources appear in Table 5.

\begin{tabular}{|c|c|c|c|}
\hline \multicolumn{4}{|c|}{ Table 5. Student Access Rates for Ancillary Resources } \\
\hline Resource Name & $\begin{array}{c}\text { \# of Students } \\
\text { (who Accessed this } \\
\text { Resource) }\end{array}$ & $\begin{array}{l}\text { Access } \\
\text { Rate }\end{array}$ & \\
\hline Experiment with converting bits to bytes & 69 & $69.0 \%$ & \\
\hline Four Basic Functions of a Computer \{web link\} & 81 & $81.0 \%$ & \\
\hline BIOS $\{$ web link $\}$ & 37 & $37.0 \%$ & \\
\hline Microprocessors $\{$ web link $\}$ & 26 & $26.0 \%$ & \\
\hline How Computer Memory Works \{web link\} & 24 & $24.0 \%$ & \\
\hline How does my Computer Think? \{web link\} & 28 & $28.0 \%$ & \\
\hline Managing and Maintaining Your Computer \{web link\} & 41 & $41.0 \%$ & \\
\hline Understanding the Parts of your Computer $\{$ web link $\}$ & 29 & $29.0 \%$ & \\
\hline How to Upgrade your Ram \{web link\} & 29 & $29.0 \%$ & \\
\hline What's New In PowerPoint 2010 & 67 & $67.0 \%$ & \\
\hline KSU ITS Training Booklets - PowerPoint 2010 & 21 & $21.0 \%$ & \\
\hline Life After Death by PowerPoint 2010 \{web link\} & 28 & $28.0 \%$ & \\
\hline What's New in Excel 2010 & 43 & $43.0 \%$ & \\
\hline KSU ITS Training Booklets - Excel 2010 & 30 & $30.0 \%$ & \\
\hline Excel 2010 Fundamentals - Part 1 \{web link\} & 11 & $11.0 \%$ & \\
\hline Excel 2010 Fundamentals - Part 2 \{web link $\}$ & 9 & $9.0 \%$ & \\
\hline Overview of Cell Referencing \{web link\} & 24 & $24.0 \%$ & \\
\hline How to do Absolute/Relative Cell References $\{$ web link & 14 & $14.0 \%$ & \\
\hline How To: Absolute/Relative Cell References $\{$ web link\} & 14 & $14.0 \%$ & \\
\hline Excel 2010 Overview of Charts \{web link\} & 33 & $33.0 \%$ & \\
\hline Excel 2010 How to Create Charts \{web link\} & 31 & $31.0 \%$ & \\
\hline Excel 2010 Tutorial on Sparklines $\{$ web link\} & 21 & $21.0 \%$ & \\
\hline What's New in Access 2010 & 51 & $51.0 \%$ & \\
\hline Access 2010 - Creating a New Blank Database \{web link\} & 18 & $18.0 \%$ & \\
\hline Access 2010 - Creating a Simple Form $\{$ web link $\}$ & 15 & $15.0 \%$ & \\
\hline Access 2010 - Creating a Table $\{$ web link $\}$ & 20 & $20.0 \%$ & \\
\hline Access 2010: Getting Started with Queries \{web link\} & 13 & $13.0 \%$ & \\
\hline Information on Basic Access 2010 Tasks \{web link\} & 36 & $36.0 \%$ & \\
\hline Anatomy of a URL \{web link $\}$ & 33 & $33.0 \%$ & \\
\hline
\end{tabular}




\begin{tabular}{|l|c|r|l|} 
More URL anatomy \{web link\} & 26 & $26.0 \%$ & \\
\hline Warriors of the What's New in & 25 & $25.0 \%$ & \\
\hline Wireless Home Network \{web link\} & 26 & $26.0 \%$ & \\
\hline Department of Homeland Security \{web link\} & 26 & $26.0 \%$ & \\
\hline How Secure Is Your Password \{web link\} & 22 & $22.0 \%$ & \\
\hline How To Change Your KSU NetID Password & 8 & $8.0 \%$ & \\
\hline KSU NetID Website \{web link\} & 9 & $9.0 \%$ & \\
\hline Web Design Basics What's New in & 15 & $15.0 \%$ & \\
\hline Creating a Web Page with Notepad \{web link\} & 49 & $49.0 \%$ & \\
\hline Digital-Images & 44 & $44.0 \%$ & \\
\hline IrfanView Access Rate for All Resources in this Category & 14 & $14.0 \%$ & \\
\hline \multicolumn{1}{|r|}{} & & & $29.0 \%$ \\
\hline
\end{tabular}

\section{Student Success}

The purpose of course materials is to facilitate student learning. In theory, it can be hypothesized that there is a relationship between student interaction with content and student success. In this study student-content interaction is measured by student access to resources. Student success is measured by the final grade received in the course. Both measures are rated on a scale of 0 to 100. The access rate of 100 indicated a student accessed $100 \%$ or all of the resources. A grade of 100 is the highest grade a student could receive. Figure 1 plots access rate by grade. A correlation analysis found a statistically significant relationship $(r=.384, \mathrm{p}<.05)$ between course resource access rate and the grade a student received. The relationship is moderately strong. The more resources a student interacts with, the greater chance they have of achieving a higher level of success in the course.

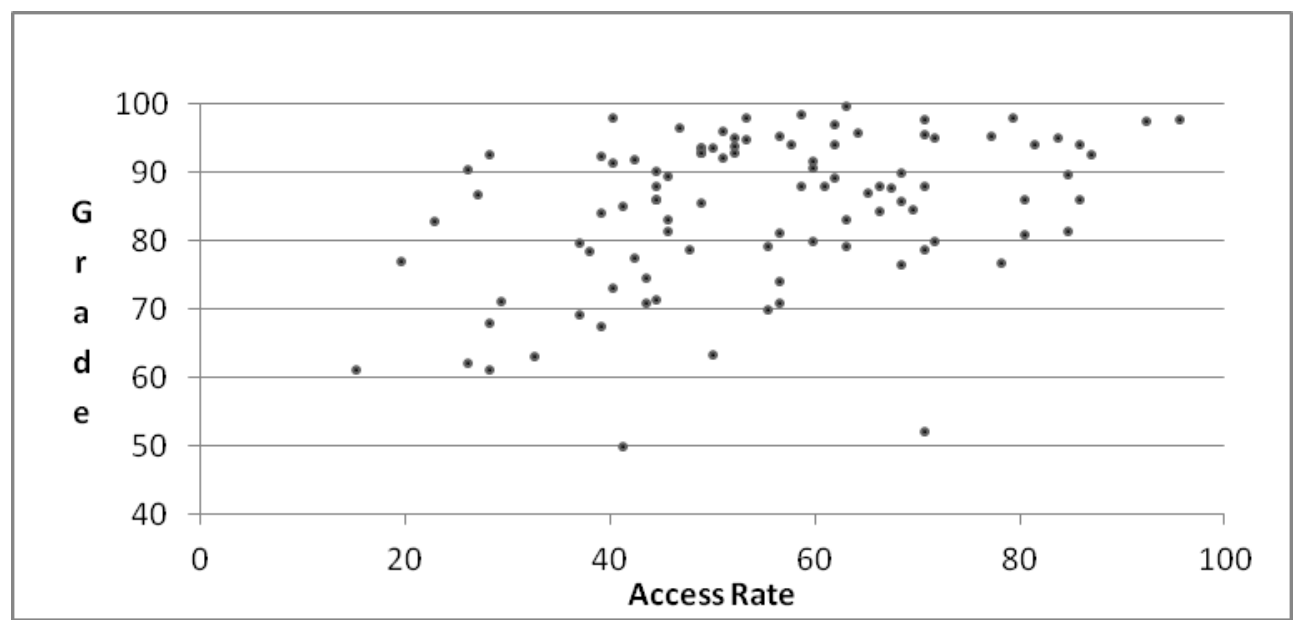

Figure 1. Course Access Rate versus Grade Received 


\section{Student Perceptions of Course Resource Access Patterns}

Students were surveyed and asked to (1) report how often they accessed course materials and (2) give their opinions on their perceptions regarding why students do, or do not, access course materials. Sixty-seven students responded to the survey. A majority of the students surveyed $(89.1 \%)$ reported that they usually, or always, accessed the weekly module guide. Interestingly, two students reported having never opened the module guides. A majority (77.6\%) also viewed the lecture notes. Fewer students reported accessing ancillary materials. Less than $20 \%$ of the students indicated they always opened the supplemental materials and only $11.9 \%$ reported they always opened the provided web links. In fact, $14.9 \%$ stated they never opened the web links. This data follows a similar pattern to the access counts tracked by the LMS. Student responses are reported in Table 6.

\begin{tabular}{|l|l|c|c|c|c|c|c|c|c|}
\hline \multicolumn{7}{|c|}{ Table 6. Student Self-Reported Access to Course Materials } \\
\hline $\begin{array}{l}\text { Resource } \\
\text { Category }\end{array}$ & \multicolumn{1}{|c|}{ Survey Question } & \multicolumn{2}{|c|}{ always } & \multicolumn{2}{|c|}{ usually } & \multicolumn{2}{|c|}{ occasionally } & \multicolumn{2}{c|}{ never } \\
\hline & How often did you open: & $\mathrm{F}$ & $\%$ & $\mathrm{~F}$ & $\%$ & $\mathrm{~F}$ & $\%$ & $\mathrm{~F}$ & $\%$ \\
\hline $\begin{array}{l}\text { Direct } \\
\text { Reference }\end{array}$ & weekly module guide? & 42 & $65.6 \%$ & 15 & $23.4 \%$ & 5 & $7.8 \%$ & 2 & $3.1 \%$ \\
\hline $\begin{array}{l}\text { Indirect } \\
\text { Reference }\end{array}$ & lecture notes? & 36 & $53.7 \%$ & 16 & $23.9 \%$ & 13 & $19.4 \%$ & 2 & $3.0 \%$ \\
\hline $\begin{array}{l}\text { Ancillary } \\
\text { Materials }\end{array}$ & supplemental materials? & 13 & $19.4 \%$ & 28 & $41.8 \%$ & 23 & $34.3 \%$ & 3 & $4.5 \%$ \\
\hline $\begin{array}{l}\text { Ancillary } \\
\text { Materials }\end{array}$ & $\begin{array}{l}\text { links to supplemental } \\
\text { materials? }\end{array}$ & 8 & $11.9 \%$ & 23 & $34.3 \%$ & 26 & $38.8 \%$ & 10 & $14.9 \%$ \\
\hline $\begin{array}{l}\text { Course } \\
\text { Support }\end{array}$ & $\begin{array}{c}\text { course orientation } \\
\text { materials? }\end{array}$ & 29 & $43.9 \%$ & 20 & $30.3 \%$ & 8 & $12.1 \%$ & 9 & $13.6 \%$ \\
\hline & & & & & & & & & \\
\hline \hline
\end{tabular}

The survey provided two sections to elicit responses to why students did or did not access course resources. The first section included open-ended questions. The second section provided a listing of four previously identified reasons and asked students to rank order them using a numeric scale where 5 represented the highest rank and 1 the lowest. Table 7 depicts student rankings. The majority of students indicated the main reason they did not access resources was due to time constraints. Not accessing resources because they were not perceived necessary to complete graded assignments received the next highest rating. In responses to the open-ended questions, several students cited that accessing resources helped them keep current with course requirements and helped them to earn higher grades. Three students indicated that the resources provided interesting information and one student commented they were motivated to "learn as much as I can." When asked to provide additional information that would help identify why other students do, or do not, access course resources, interesting patterns emerged. Several respondents suggested that the reasons students do not access course materials is a lack of effort by students who are in a rush to complete assignments as their primary goal is simply to pass the course. This sentiment is supported by other comments that suggested students might not open resources they perceive will not help them complete an assignment or improve their grade. 
Table 7. Student Ranking of Reasons Not to Access Course Resources

\begin{tabular}{|c|c|c|c|c|c|c|}
\hline & \multicolumn{5}{|c|}{ \# of Students Reporting } & \multirow{2}{*}{$\begin{array}{l}\text { Weighted } \\
\text { Ranking }\end{array}$} \\
\hline & \multicolumn{5}{|l|}{$\begin{array}{l}\text { Highest } \\
\text { Lowest }\end{array}$} & \\
\hline & 5 & 4 & 3 & 2 & 1 & \\
\hline Did not have enough time & 18 & 13 & 11 & 11 & 3 & 3.57 \\
\hline Did not think the material had value & 3 & 10 & 10 & 14 & 19 & 2.36 \\
\hline $\begin{array}{l}\text { Did not think resources were necessary } \\
\text { to complete graded assignments }\end{array}$ & 19 & 11 & 12 & 9 & 5 & 3.54 \\
\hline $\begin{array}{l}\text { Do not generally open resources not } \\
\text { part of a graded assignment }\end{array}$ & 12 & 15 & 18 & 9 & 2 & 3.46 \\
\hline $\begin{array}{l}\text { Did not realize the resources were } \\
\text { available }\end{array}$ & 8 & 6 & 5 & 9 & 28 & 2.23 \\
\hline
\end{tabular}

\section{Conclusions}

This study supports the finding that educational materials facilitate the achievement of desired learning outcomes (Brown \& Voltz, 2005). In determining overall patterns of access to course content, students report a tendency to retrieve only content that they perceive to be necessary to complete course deliverables directly tied to course assessment. Student satisfaction with online learning aligns with one specific course outcome - the grade - rather than with any process. Combined with research findings that e-learning systems require self-regulated learning (Eom \& Wen, 2006), these results represent implications for course designers. Perhaps interactive content that gives instantaneous and frequent performance feedback will be most likely to be perceived as relevant and useful to students. Moreover, maybe such content will enable the shift advocated by Eom and Wen (2006) - from outcome to process, from producing to learning.

Four research questions posed were answered as follows. Students clearly tend to access only course materials that they perceive to be directly tied to earning a good grade. High access rates are associated with high grades. Student recollections and perceptions of their access to course resources align closely with actual access rates, as verified within the LMS system. Lastly, time constraints are cited as the main reason for not accessing course resources; this is consistent with the first finding, as time-pressured students prioritize resources and access only materials that are perceived to be helpful in completing assignments.

Online learning is an increasingly vital dimension in the course delivery portfolios of most institutions of higher education (Mayadas et al., 2009). Increased access and convenience are often cited as primary catalysts by both institutions and students. Research is beginning to emerge that indicates that students in well-designed courses delivered online via a learning management system frequently outperform students in similar face-to-face courses. Effective and well-designed online courses facilitate and emphasize interaction between student, teacher, and content. Interaction between students and content has been shown to be particularly crucial to learning in an asynchronous online course. Anderson (2003) theorizes that deep and meaningful learning takes place when student-content interaction is supported at a high level. To facilitate this high level of interaction, students must access course resources. Our study confirmed that students do indeed access course resources, albeit selectively. Much can be gained by further study of the processes by which students decide what content to retrieve. For the most part, students access content and 
resources that provide direct support or guidance for completing course requirements and assessments. Students are less likely to actively engage with course materials that they perceive to be ancillary or secondary. The implications for course design are obvious and significant, pointing to the benefits of weaving course content into a cohesive, compelling tapestry.

\section{References}

Allen, I. E., \& Seaman, J. (2011). Going the distance: Online education in the United States, 2011. Babson Survey Research Group. Available from: http://sloanconsortium.org/publications/survey/going_distance 2011

Anderson, T. (2003). Getting the mix right again: An updated and theoretical rationale for interaction. International Review of Research in Open and Distance Learning, 4(2). Available from http://www.irrodl.org/index.php/irrodl/article/view/149/708

Aud, S., Hussar, W., Kena, G., Bianco, K., Frohlich, L., Kemp, J., \& Tahan, K. (2011). The condition of education 2011 (NCES 2011-033). U.S. Department of Education, National Center for Education Statistics. Washington, DC: U.S. Government Printing Office.

Bollinger, D. U., \& Wasilik, O. (2009, May). Factors influencing faculty satisfaction with online teaching and learning in higher education. Distance Education, 30(1), 103-116.

Brooks, M. (2009). The excellent inevitability of online courses. Chronicle of Higher Education. Available from http://chronicle.com/article/The-Excellent-Inevitability-of/44251/

Brown, A., \& Voltz, B. (2005). Elements of effective e-learning design. The International Review of Research in Open and Distance Learning, 6(1). Available from http://www.irrodl.org/index.php/irrodl/article/view/217

Eom, S. B., \& Wen, H. J. (2006, July). The determinants of students' perceived learning outcomes and satisfaction in university online education: An empirical investigation. Decision Sciences Journal of Innovative Education, 4(2), 215-235.

Fain, P. (2010). Hard times require better planning and more online offerings, speakers tell publicuniversity leaders. Chronicle of Higher Education. Available from: http://chronicle.com/article/HardTimes-Require-Better/125404/

Greenberg, G. (2010). Conceptions of quality in course design for web-supported education. Proceedings of the $26^{\text {th }}$ Annual Conference on Distance Teaching \& Learning. Madison, WI. Available from http://www.uwex.edu/disted/conference/Resource_library/proceedings/28667_10.pdf

Haley, K. N. (2010). Wired and tired: The cool and the agony of teaching online. Social Work Review, 1, 58-63.

Koszalka, T. A., \& Ganesan, R. (2004). Designing online courses: A taxonomy to guide strategic use of features available in course management systems (CMS) in distance education. Distance Education, 25(2), 243-256.

Legon, R. (2006). Comparison of the quality matters rubric to accreditation standards for distance learning. Pasadena, MD: copaP-Quality Matters.

Legon, R., \& Runyon, J. (2007). Research on the impact of the quality matters course review process. $23^{\text {rd }}$ Annual Conference on Distance Teaching \& Learning. Madison, WI August 8-10, 2007. Available from http://www.uwex.edu/disted/conference/Resource_library/proceedings/07_5284.pdf

Mayadas, F. A., Bourne, J., \& Bacsich, P. (2009). Online education today. Science, 323(5910), 85-89.

Means, B., Yoyama, Y., Murphy, R., Bakia, M., \& Jones, K. (2010). Evaluation of evidence-based practices in online learning a meta-analysis and review of online learning studies. Washington, D.C.: U.S. Department of Education. Available from http://www2.ed.gov/rschstat/eval/tech/evidence-basedpractices/finalreport.pdf 
Moore, M. (1989). Three types of interaction. The American Journal of Distance Education, 3(2) 1-6. Available from http://www.ajde.com/Contents/vol3_2.htm\#editorial

Nagel, D. (2009). Most college students to take classes online by 2014. Campus Technology. Available from http://campustechnology.com/articles/2009/10/28/most-college-students-to-take-classes-onlineby-2014.aspx

Quality Framework Narrative: The 5 Pillars. (n.d.). Sloan Consortium. Available from http://sloanconsortium.org/Quality_Framework_Narrative_5_pillars

Quality Matters. (2011). Overview and introduction presentation to the quality matters program. Available from www.qmprogram.org/applying-rubric-2/download/QM Overview 2011.pdf

Ralston-Berg, P., \& Nath, L. (2008). What makes a quality online course? The student perspective. Proceedings of the $24^{\text {th }}$ Annual Conference on Distance Teaching and Learning. Madison, WI. Available from http://www.uwex.edu/disted/conference/Resource_library/proceedings/08_12876.pdf

Redden, E. (2009). In global recession, global ed still growing. Inside Higher Ed. Available from http://www.insidehighered.com/news/2009/05/29/international

Shachar, M., \& Neumann, Y. (2010, June). Twenty years of research on the academic performance differences between traditional and distance learning: Summative meta-analysis and trend examination. MERLOT Journal of Online Learning and Teaching. 6(2). Available from http://jolt.merlot.org/vol6no2/shachar_0610.pdf

Siragusa, L., Dixon, K. C., \& Dixon, R. (2007). Designing quality e-learning environments in higher education. ICT: Providing choices for learners and learning. Proceedings ascilite Singapore 2007. Available from http://www.ascilite.org.au/conferences/singapore07/procs/siragusa.pdf

Sloan Consortium. (2002). Quick guide: Pillar reference manual. Available from http://www.sloanc.org/publications/books/dprm_sm.pdf

\section{Biographies}

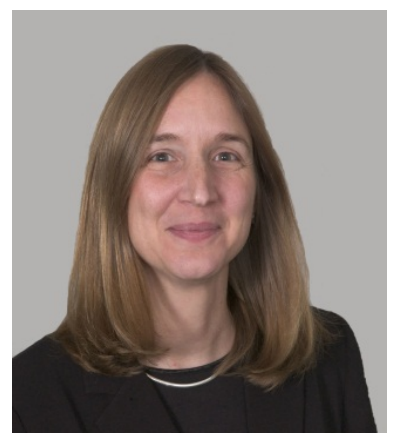

Meg Coffin Murray is a Professor in the Department of Computer Science and Information Systems at Kennesaw State University. She holds a Ph.D. in Information Systems and has over thirty years of experience in both academe and industry. Dr. Murray specializes in the development and implementation of emerging technologies to meet business and societal needs with a special interest in technology infusion in healthcare and in education. Her current work devises strategies to assess and remediate skills needed to leverage IT in innovation, a primary driver of economic growth.

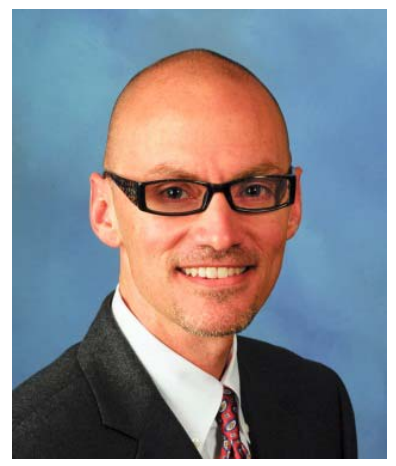

Jorge Pérez is Faculty Executive Assistant to the President and Associate Professor of Information Systems at Kennesaw State University. He holds a Ph.D. in Information Systems from Florida State University, and has two decades of experience in the field as a consultant, systems analyst, web developer, and educator. Professor Pérez has published research on information security, diffusion of innovations, information systems curriculum, and e-learning. His current research on information technology literacy centers on identifying, measuring, and amplifying competencies needed by computer and Internet users. 


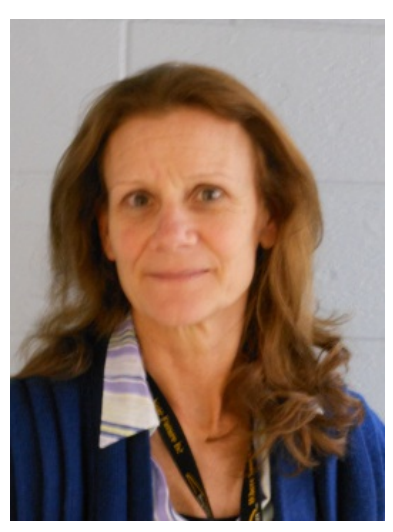

Debra Geist is a Lecturer of Information Systems at Kennesaw State University. With over thirty years in the field of Information Technology, she has collaborated with professionals from the private, public, government and academic sectors to accommodate technical needs and achieve competitive advantage through the application of information systems. Her background, combined with her first-hand experience of the evolution of technology, provide a wealth of knowledge to contribute to the pursuit of promoting digital literacy in the classroom and researching distance learning methodologies.

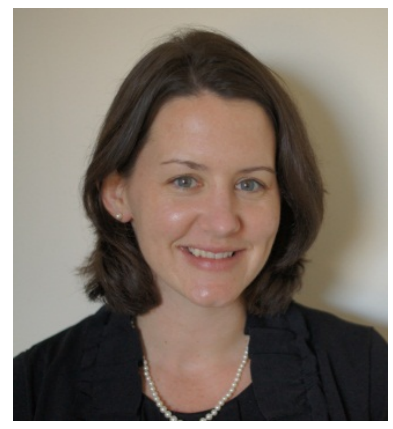

Alison Hedrick is a Lecturer of Information Technology in the Department of First-Year Programs at Kennesaw State University. She holds a M.S. in Information Systems from Kennesaw State University, and has six years of experience as an IT professional. She currently teaches hybrid and online sections of a digital literacy course. 